\title{
THE CONCEPT OF MAHABBAH PERSPECTIVE OF RABI'ATUL ADAWIYAH
}

\author{
Siti Asiah \\ Sekolah Tinggi Agama Islam Darul Kamal \\ Nahdlatul Wathan Kembang Kerang, Lombok Timur \\ dkbelief@gmail.com
}

Abstract - The Divine love story of Rabi'atul Adawiyah is one of the legendary stories that has been told from time to time. This story has washed away many hearts of listeners, especially those who want to be one with God. However, this story is often only used as a fairy tale that leaves no mark on the listeners, even though this story gives a great awareness of the importance of one's love for others and of course for God. Rabiatul Adawiyah appeared as a tough woman not necessarily a great lover, but was born from the womb of a life full of struggles. His life experiences, socio-political conditions, his views on world life, and the existence of his God became a long process in his search for and discovering the concept of divine love.

Keywords: Divine Love, Social-Historical, and Rabiatul Adawiyah

\section{KONSEP MAHABBAH RABI'ATUL ADAWIYAH}

Abstrak - Kisah Cinta Ilahiah Rabi'atul Adawiyah adalah salah satu kisah legendaris yang telah diceritakan dari masa ke masa. Kisah ini telah menghanyutkan banyak hati pendengarnya terutama hati yang ingin menyatu dengan Tuhannya. Namun demikian, kisah ini tak jarang hanya dijadikan sebagai dongeng yang tak meninggalkan bekas bagi pendengarnya, padahal kisah ini memberikan kesadaran yang besar terhadap pentingnya cinta seseorang kepada sesama dan tentu kepada Tuhannya. Rabi'atul Adawiyah tampil sebagai perempuan tangguh tidak serta merta menjadi pecinta yang agung, melainkan lahir dari rahim kehidupan yang penuh perjuangan. Pengalaman hidupnya, keadaan sosial-politik, pandangannya terhadap kehidupan dunia, dan keberadaan Tuhannya menjadi proses panjang dalam pencarian dan penemuan konsep cinta ilahiahnya.

Kata Kunci: Cinta ilahiah, Sosial-Historis, dan Rabiatul Adawiyah

\section{PENDAHULUAN}

Rabi'atul Adawiyah adalah seorang perempuan yang terkenal dengan kisah hidup dan keromantisannya dengan sang khalik. Cerita yang diawarkan tentang hidupnya tak pernah jauh dari bagaimana ia mencintai Allah, bagaimana ia menjadikan Allah sebagai satu-satunya yang ia inginkan, satu-satunnya tujuan yang ingin diraihnya. Namun demikian, kisah cinta yang seringkali menjadi perhatian ini merupakan hasil dari rentetan pengalaman hidupnya yang panjang. Lahir dari maqam yang ia dapatkan setelah melewati tangga-tangga kehidupan. Rabiah menemukan kenikmatan cinta sembari bertarung dengan pahitnya kehidupan, dengan berbagai rintangan yang dihadapi.

Pengalaman hidupnya dari semenjak kecil bahkan sebelum ia dilahirkan telah menunjukkan perjuangan Rabi'ah dalam menjalani kesulitan hidupnya. Ia lahir dari keluarga yang miskin namun dengan ketaatan serta kezuhudan yang mendalam. Sifat dan karakter ini 
kemudian diwarisi oleh Rabi'ah. Bukan hanya tentang keimanan, orang tuanya juga mewarisi sikap mandiri kepada Rabi'ah, sehingga setelah orang tuanya meninggal, meskipun dalam keadaan bersusah payah Rabi'ah dan kakaknya tetap berusaha meneruskan hidupnya. Bahkan setelah terpisah dengan kakaknya, Rabi'ah tidak pernah menyerah. Tidak dengan hidupnya, lebih-lebih dengan keimanannya.

Pengalaman hidup seseorang, membentuk pola pikir dan sudut pandangnya dalam menjalani kehidupan. Selain dalam keluarga, keadaan masyarakat Bashrah pada saat itu juga meyakinkan Rabi'ah bahwa kehidupan dunia adalah malapetaka, sedang ketenangan yang murni hanyalah milik dan bersama Allah. Tapi benarkah cinta Rabi'ah adalah cinta yang hanya ingin ia tunjukkan dan persembahkan untuk Allah? Tidak ada tujuan lain yang ia ingingkan? Mengingat ia menjadi kisah legenda cinta yang tak pernah usang, maka kisah ini adalah cerita yang telah didengar, dilihat dan disaksikan oleh banyak orang. Sementara persolan cinta adalah sesuatu yang ada di dalam hati terlebih cinta kepada Allah, harusnya ia menjadi rahasia antara Rabi'ah dengan Tuhannya.

Selain itu, kisah cinta Rabi'ah seringkali dikemas seperti kisah cinta langit, cinta Ilahiah yang seolah-olah tak bisa digapai karena peberian dari Allah yang nampak hanya diberikan kepada Rabi'ah. Bahkan seringkali cerita ini diceritakan seperti dongeng penghantar tidur kemudian meninggalkan kesan yang mengagumkan namun tak berbekas pada pagi harinya. Kesan-kesan yang diceritakan memang seringkali tanpa cacat, cinta yang mendekati kesempurnaan yang terasa jauh untuk digapai. Cerita ini nampak seperti cerita yang terjadi di suatu masa dan berhenti pada masa itu, cinta yang dimiliki dan dilahirkan oleh seseorang kemudian menjadi miliknya saja. Oleh sebab itu penting membaca dan menguraikan kembali perjalanan hidup Rabiatul Adawiyah dan berbagai persolan yang terjadi dalam hidupnya serta sosio historis yang melingkupinya secara keseluruhan sebelum beranjak pada kisah cinta ilahiah.

\section{PEMBAHASAN}

\section{Sejarah singkat tentang Rabi'atul Adawiyah}

Rabi'atul Adawiyah adalah seorang sufi perempuan yang memiliki nama lengkap Rabi'ah binti Isma'il Al-Adawiyah Al-Qisysyiyyah. Lahir pada tahun 95 H/717 M di suatu perkampungan dekat kota Basrah, Irak. Nama Rabi'ah diberikan oleh ayahnya Ismail karena ia terlahir sebagai putri keempat dalam keluarganya.

Rabi'ah lahir dari keluarga yang miskin, diceritakan bahwa pada malam kelahirannya tidak terdapat apapun yang dapat digunakan untuk menutupi dan menghangatkan tubuh Rabi'ah kecil. Bahkan tidak terdapat setitis minyak untuk mengoles pusatnya apalagi untuk lampu penerang rumah. ${ }^{1}$ Meski demikian, Rabiah lahir dan menjadi putri dari orang tua yang takwa. Ayahnya Ismail adalah orang yang sangat zuhud dan selalu berzikir kepada Allah swt. Dalam keadaan yang mendesakpun ia tetap menjaga kehormatan dan kesucian diri dan keluarganya dari meminta-minta kepada orang lain.

Kisah yang menarik tentang kezuhudan ayahnya adalah ketika Rabi'ah lahir tanpa ada kain yang menutupinya, sang ibu meminta ayah Rabiah untuk meminta bantuan kepada tetangganya. Ayahnyapun pergi menuju rumah tetangganya, namun hanya berdiri di depan

\footnotetext{
${ }^{1}$ Abu Ubaidillah Syariff, Kisah Rabiah al-Adawiyah:Sufi Wanita dan Aroma Cinta Ilahi, (Kuala Lumpur: Jasmin Enterpaise, $\mathrm{tt}), 33$.
}

The Concept of Mahabbah ... | 32 
rumah dan tidak mengetuk pintu. Kemudian ia kembali dan memberitahukan istrinya bahwa tetangganya sudah tidur. Dengan perasaan hawatir, Ismailpun tertidur. Dalam tidurnya ia bermimpi berjumpa dengan rasulullah saw, beliau berkata "Janganlah engkau bersedih hati, karena putrimu yang baru lahir itu kelak akan menjadi orang yang terhormat dan tujuh puluh ribu dari umatku memerlukan syafaatnya." Dalam mimpi itu ia juga diperintahkan Nabi untuk menemui dan memberikan surat kepada seorang amir, Isa Zaidan. Isi surat itu "Wahai amir, engkau biasanya membaca shalawat seratus kali setiap malam dan empat ratus kali setiap malam jumat. Tetapi dalam jumat terakhir engkau lupa melaksanakannya. Oleh karena itu, hendaklah engkau membayar empat ratus dinar kepada orang yang membawa surat ini, sebagai kaffarah atas kelalaianmu." Pada pagi harinya, ayah Rabi'ah menulis sepucuk surat seperti yang dipesankan Rasulullah dan pergi menemui amir. ${ }^{2}$

Berdasarkan kisah di atas, kehidupan Rabi'ah telah terpelihara dari barang-barang subhat, lebih-lebih barang yang diperoleh dengan maksiat. Bahkan rabi'ah tak segan-segan menanyakan makanan yang dibawa pulang ayahnya. Ia tidak ingin ayahnya menyediakan makanan yang tidak halal, bahkan ia mengatakan lebih baik menahan lapar di dunia daripada menahan azab di akhirat.

Ketika masih kecil, Rabi'ah adalah gadis yang shalihah. Terlebih setelah ibu dan ayahnya meninggal. Ia menjadi yatim piatu yang tidak mewarisi harta benda dari orang tuanya, sedangkan kakaknya juga masih belum dewasa. Dalam usia yang masih muda belia, Rabi'ah dan kakak-kakaknya harus mencari pekerjaan untuk melanjutkan hidupnya. ${ }^{3}$ Satu-satunya peninggalan orang tuanya yang bisa dimanfaatkan adalah sebuah perahu kecil, yang biasa dipakai ayahnya untuk mencari nafkah. Rabi'ah kemudian melanjutkan pekerjaan ayahnya menyeberangkan orang-orang di sungai Dajlah. Diantara ketiga kakaknya, Rabi'ahlah yang paling mandiri, hal ini karena ia sering diajak ayahnya bekerja menyeberangkan orang-orang menggunakan perahu tersebut. Namun demikian, tidak berarti kakak-kakaknya tidak berkerja, mereka bekerja di rumah, menenun kain atau memintal benang.

Menurut Qindil, Rabi'ah dan kakak-kakaknya keluar masuk kampung, mengetuk rumah-rumah untuk menawarkan jasa, barangkali ada pekerjaan yang dapat mereka bantu. Meski demikian, kehiduan Rabi'ah yang penuh dengan perjuangan tak menyurutkan keimanan dan ketakwaannya kepada Allah swt justru sebaliknya, pada usia remaja inilah Rabi'ah mulai menampakkan rasa cintanya kepada Allah swt.

Pada masa selanjutnya, kehidupan Rabi'ah semakin sulit, terlebih ketika kota Bashrah menjadi kota segala aliran dan pertentangan antara satu suku dengan suku lainya. Pertentangan tersebut tidak terleas dari situasi politik yang terjadi ketika itu. Kota Bashrah yang menjadi pusat ilmu pengeahuan itu berubah menjadi pusat pertentangan. Di kota tersebut terdapat pengikut khawarij dan syi'ah yang fanatik. Hal ini menjadi puncak munculnya pemberontakan-pemberontakan antara peduduk Bashrah. Pertentangan antara aliran tersebut menyebabkan pertumpahan darah.

Selanjutnya kota Bashrah mengalami bencana alam berupa kemarau panjang, kekeringan yang berkepanjangan menyebakan kelaparan penduduk kota. Kota yang mulanya makmur dan berkembang, berubah menjadi kota yang dilanda kemiskinan. Keadaan diperparah dengan meningkatnya pencurian dan perampokan. Hal ini tidak hanya membuat

\footnotetext{
2 Abu Ubaidillah Syariff, Kisah Rabiah al-Adawiyah:Sufi Wanita..., 34.

${ }^{3}$ Abu Ubaidillah Syariff, Kisah Rabiah al-Adawiyah:Sufi Wanita..., 43.
} 
menderita, tetapi juga dilanda ketakutan. Orang miskin semakin miskin dan terlunta-lunta, mereka sering dihadang perampok kemudian dijual sebagai hamba. ${ }^{4}$ Peristiwa ini pula yang terjadi kepada Rabi'ah. Saat perjalanannya, ia diculik oleh seorang perampok. Rabi'ah kemudian jatuh ke tangan perampok dan dijual sebagai hamba sahaya dengan harga yang sangat murah, yaitu enam dirham.

Kehidupan Rabi'ah sebagai seorang hamba tentu lebih menyakitkan. Hidupnya kini bukan lagi miliknya melainkan milik tuannya. Seseorang yang memperlakukannya dengan sangat kasar, tanpa prikemanusiaan dan belas kasih. Tubuh Rabi'ah semakin kering dan kurus, makanan yang dimakannya hanyalah sisa dari tuannya. Pakaiannyapun hanya sepotong, itu pun telah compang-camping. ${ }^{5}$ Musibah yang tiada henti menimpanya tidak membuatnya putus asa dan membuanya mengeluh, justru hal ini semakin membuat Rabi'ah lebih dekat dengan sang Ilahi. Ia tetap menjalani kehidupannya sebagai orang yang tabah dan sabar, selalu taat pada perintah Allah dengan melaksanakan ibadah-ibadah yang biasa ia lakukan.

Rabi'ah mencapai usia kurang lebih 90 tahun. Pada saat-saat terakhir hidupnya, ia tidak ingin menyusahkan orang lain. Menurut al-Attar ketika tiba waktunya Rabi'ah akan meninggalkan dunia yang fana ini, Rabi'ah meminta orang-orang yang menunggunya meninggalkan kamarnya kemudian Rabi'ah meninggal dunia dalam keadaan tenang. Terdapat perbedaan di kalangan ahli sejarah tentang tahun dan tempat penguburannya. Mayoritas menyebutkan tahun 185 sebagai tahun wafatnya sedangkan makamnnya berada di kota kelahirannya.

\section{Terminologi Mahabbah (Cinta Ilahiah)}

Pengertian mahabbah sejatinya telah dijelaskan oleh banyak ulama dan intelektual, meskipun demikian pengertian-pengertian ini sering kali diahiri dengan kalimat yang menunjukkan betapa sulitnya mendefinisikan mahabbah/cinta ini. Jika merujuk ke dalam Kamus Besar Bahasa Indonesia, cinta berarti suka sekali, sayang benar, kasih sekali, terpikat, ingin sekali, berharap sekali, rindu, dan lain-lain. ${ }^{6}$ Dalam bahasa Arab, kata yang paling banyak digunakan dalam al-Qur'an untuk menunjuk makna Cinta adala kata Hub (حب). Dengan berbagai bentuknya, kata ini terulang sebanyak 93 kali. $^{7}$

Kalau kita merujuk kepada kaum sufi, cinta atau mahabbah merupakan salah satu tahapan-tahapan perjalanan menuju Tuhan. Abu al-Qasim Abdul Karim al-Qusyairi (465 H/1072) misalnya, mengartikan cinta sebagai mementingkan kekasih dari sahabat. Maksudnya, mementingkan hal-hal yang diridhai kekasih (baca; Allah swt) daripada kepentingan ego. Sufi besar Abu al-Qasim al-Junaid (297 H/910 M) menjelaskan tentang tanda-tanda pecinta Allah:

"Anda menemukan dirinya tidak menoleh kepada dirinya lagi, selalu dalam hubungan harmonis dengan Tuhan melalui zikir, senantiasa menunaikan hak-hak-Nya, memandang kepadanya dengan mata hati, terbakar hatinya oleh sinar hakikat ilahi, meneguk minum dari gelas cinta kasih-Nya,

\footnotetext{
${ }^{4}$ Abu Ubaidillah Syariff, Kisah Rabiah al-Adawiyah:Sufi Wanita..., 49.

${ }^{5}$ Hasan Bakti Nasution dan Sahrini Harap. Ensiklopedi Aqidah Islam. (Jakarta: kencana. 2003), 347.

${ }^{6}$ Dadang Sunendar, dkk, KBBI V 0.4.0 Beta (40), Kementerian Pendidikan dan Kebudayaan Republik Indonesia; Badan Pengembangan Bahasa dan Perbukuan, 2016

${ }^{7}$ M. Quraish Shihab, Perempuan, (Tanggerang: Lentera Hati, 2018), 90

The Concept of Mahabbah ... $\mid 34$
} 
tabirpun terbuka baginya sehingga sang Mahakuasa muncul dari tirai-tirai gaib-Nya. Maka tatkala berucap, dengan Allah ia; tatkala berbicara, demi Allah ia; tatkala diam, bersama Allah ia. Sungguh, dengan, demi, dan bersama Allah selalu ia".

Prof. Dr. Harun Nasution menjelaskan pengertian mahabbah yaitu, memeluk kepatuhan kepada Tuhan dan membenci sikap melawan-Nya, menyerahkan seluruh diri kepada yang dikasihi, dan mengosongkan hati dari segala-galanya, kecuali dari yang dikasihi. Dalam al-Qur'an terdapat banyak ayat yang menjelaskan dan menunjukkan tentang cinta: misalnya Qs. al-Anfal: 2

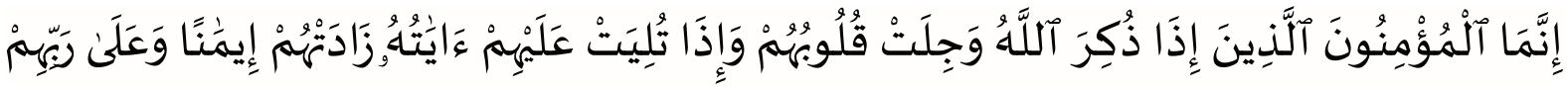

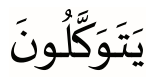

Sesungguhnya orang yang beriman ialah orang-orang yang bila disebut nama Allah gemetar hati mereka, dan bila dibacakan ayat-ayat Allah bertambahlah iman mereka. Dan kepada Tuhannyalah mereka bertawakkal (Qs. al-Anfal: 2)

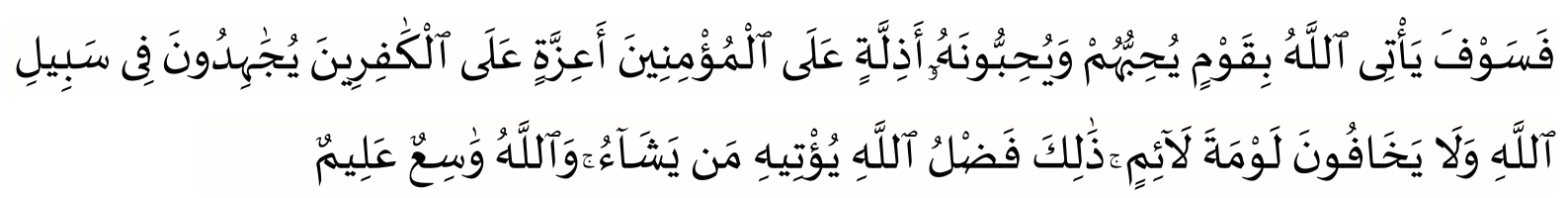

Maka kelak Allah akan mendatangkan suatu kaum yang Allah mencintai mereka dan merekapun mencintai-Nya, yang bersikap lemah lembut terhadap orang yang mukmin, yang bersikap keras terhadap orang-orang kafir, yang berjihad dijalan Allah, dan yang tidak takut kepada celaan orang yang suka mencela. Itulah karunia Allah, diberikan-Nya kepada siapa yang dikehendaki-Nya, dan Allah Maha Luas (pemberian-Nya), lagi Maha Mengetahui.

Berkaitan dengan hal ini, al-Hujwiri menjelaskan bahwa cinta manusia kepada Tuhannya adalah suatu kualiti yang menjelma dalam hati orang beriman dan taat dalam bentuk penghormatan dan pengagungan sehingga ia berusaha menjadi yang terbaik bagi yang dicintainya. ${ }^{9}$

\section{Konsep Mahabbah Rabiatul Adawiyah}

Sebagian besar para sufi menjadikan cinta sebagai ajaran pokok dalam tasawuf. Cinta adalah keadaan rohani yang tinggi dan yang penting dalam hubungan manusia dengan Allah. Dalam masalah cinta, al-Hallaj mewariskannya dalam bentuk puisi atau prosa. Sedangkan yang dianggap pertamakali menyatakan cinta kepada Allah dalam bentuk puisi adalah Yahya bin Muaz al-Razi.

Masih berbicara cinta sebelum Rabi'ah, tampil Hasan Bashri, seorang zahid yang mengatakan "Barang siapa yang mengenal Tuhannya maka dia akan mencintai-Nya, dan barang siapa yang mengenal dunia maka dia akan bersikap zuhud. Bagaimana mungkin seseorang mencintai dirinya sendiri dan tidak mencintai Tuhan yang telah menciptakan

\footnotetext{
${ }^{8}$ M. Quraish Shihab, Perempuan..., 92

${ }^{9}$ Abu Ubaidillah Syariff, Kisah Rabiah al-Adawiyah:Sufi Wanita..., 73
} 
dirinya?." 10 Meski demikian, konsep cinta yang berkembang telah disandarkan kepada Rabi'atul Adawiyah di kalangan para sufi. Sebelumnya terdapat perbincangan tentang khauf (rasa takut) dan raja' (pengharapan) yang dirintis oleh Hasan al-Bashri, namun Rabi'ah merintis jalan cinta kepada Allah.

Abu al-Wafa' al-Ghanimi al-Taftazani menyimpulkan bahwa Rabi'ah bukan hanya mempopulerkan kata cinta, tetapi dia pula yang pertama-tama menganalisis dan menguraikan pengertian cinta. Margaret Smih mengatakan bahwa Rabi'ah mungkin yang pertama menekankan cinta sebagai doktrin dan menghubungkannya dengan doktrin kasyf. Ia juga menyebutkan bahwa Rabi'ah ialah yang pertama mengajarkan konsep cinta kepada Allah tanpa mengharapkan balasan, sebuah konsep baru bagi para sufi yang kala itu sebagian besar meyakini tentang pengabdian kepada Allah karena takut atas siksa dan mengharapkan pahala/syurga. Tujuan hidup mencari akhirat dinilai sebagai tabir menyesatkan yang wajib dilenyapkan. Harapan surga dan neraka dihina sebagai pedagang mencari laba dan ganti rugi. ${ }^{11}$

Konsep Mahabbah Rabi'atul Adawiyah telah populer di kalangan para sufi. Pada masa selanjutnya konsep ini terus berkembang dan diperluas dengan wawasan baru sesuai dengan cara berfikir dan perkembangan yang ada. Ketika Rabi'ah memilih menempuh jalan hidup zuhud dan bergabung dengan kehiduan para sufi, ia mencoba meluruskan dan meningkatkan jalan para sufi dari beribadah kepada Allah karena takut neraka dan mengharapkan syurga menjadi beribadah karena Allah. Ia merasa heran terhadap orang-orang yang beribadah dengan tujuan tersebut. Ia berfikir bagaimana jika syurga dan neraka tidak pernah ada, apakah mereka tidak akan beribadah kepada Allah?. ${ }^{12}$ Berdasarkan pemikiran ini, Rabi'ah memasyarakatkan teori cinta ilahiah, sebuah cinta yang tulus tanpa mengharap balasan apapun dari Allah selain Zat-Nya sendiri. Falsafah Al-hubb dari Rabi'ah terungkap dalam kata-katanya sebagai berikut

"Tak ada jarak antara yang mencintai dan yang dicintai. Cinta adalah pengungkapan dari rasa rindu, penuturan perasaan : barangsiapa merasakan ia akan mengenal. Barangsiapa menuturkan, ia sendiri tidak dapat dituturkan. Bagaimana engkau akan menuturkan sesuatu, sedangkan engkau sendiri lenyap di khadirat-Nya, lebur dengan wujud-Nya, sirna karena menyaksikan-Nya dalam kondisi sehat engkau mabuk dibuat-Nya. Dengan memusatkan perhatian kepada-Nya engkau menjadi mantap. Dengan bersenang-senang dengan-Nya engkau menjadi sedih. Rasa takut membenteng lisan untuk bicara. Rasa bingung menahan hati untuk mengungkapkan sesuatu. Rasa cemburu mendinding mata untuk melihat. Rasa kebesaran mengikat akal untuk mengaku. Tiada dalam cinta, selain kebesaran yang langgeng, kebingungan yang melekat, hati yang rindu, rahasia yang tertutup, badan yang terasa sakit dan tidak aman, cinta dengan segala keunggulannya telah menguasai hati". ${ }^{13}$

Syair lain yang menggambarkan konsep cinta ilahiah Rabi'ah adalah

Aku mencinttaimu dengan dua cinta

Cinta karena diriku dan cinta karena Dirimu

Cinta Karena Diriku

Adalah keadaanku senaniasa mengingat-Mu

\footnotetext{
${ }^{10}$ Abu Ubaidillah Syariff, Kisah Rabiah al-Adawiyah:Sufi Wanita..., 89.

11 Simuh, Tasawuf dan Perkembangan Dalam Islam (Jakarta: RajaGrafindo Persada, 1996), 30

12 Abu Ubaidillah Syariff, Kisah Rabiah al-Adawiyah:Sufi Wanita..., 96.

13 Al-Faqi, Muhammad, Al-Tasawwuf Hayat wa Suluk, (Kairo; 1979). 34.
} 
Cinta karena Diri-Mu adalah keadaanmu yang menyingkap tabir hingga engkau kulihat

Baik untuk ini ataupun untuk itu pujian bukanlah bagiku

Bagni-Mulah pujian untuk semuanya ${ }^{14}$

Imam al-Ghazali memberikan penjelasan terkait sya'ir tersebut dengan mengatakan, bahwa mungkin yang dimaksud dengan cintta karena kesenangan (hubb al-hawa) adalah cinta kepada Allah karena kebaikan dan kenikmatan-kenikmatan yang dianugerahkan Allah kepada Rabi'ah. Sedangkan yang dimaksud dengan cinta karena Allah adalah karena Dia adalah zat yang berhak mendapat kecintaan, karena keindahan dan keagungan-Nya yang tersingkap untuk Rabi'ah. Maka hal ini sesuai dengan berkenaan dengan sebab cinta yang dilontarkan al-Ghazali: pertama, cinta itu timbul karena mencintai diri sendiri, atau keabadian diri. Rabi'ah cinta kepada Allah karena ingin selalu bersama Allah dengan selalu mengingat-Nya dan ingin abadi di sisi-Nya. Kedua, cinta timbul karena yang dicintai itu sendiri, yang patut atau berhak dicintai. Bagi Rabi'ah, Allah adalah satu-satunya yang berhak mendapat cintanya, karena Keagungan-Nya, Kemulian-Nya, Ketinggian-Nya, dan KeindahaNya. Barangkali, karena segalanya disandarkan kepada Allah, sehingga menjadikan cinta Rabi'ah disimpulkan sebagai cinta tanpa mengharapkan balasan.

Menurut Rabi'ah, cinta merupakan cetusan dari perasaan rindu dan pasrah kepada Allah, seluruh ingatan dan perasaannya tertuju kepada-Nya. Hal ini dapat terlihat dalam gubahan prosanya yang syahdu sebagai berikut:

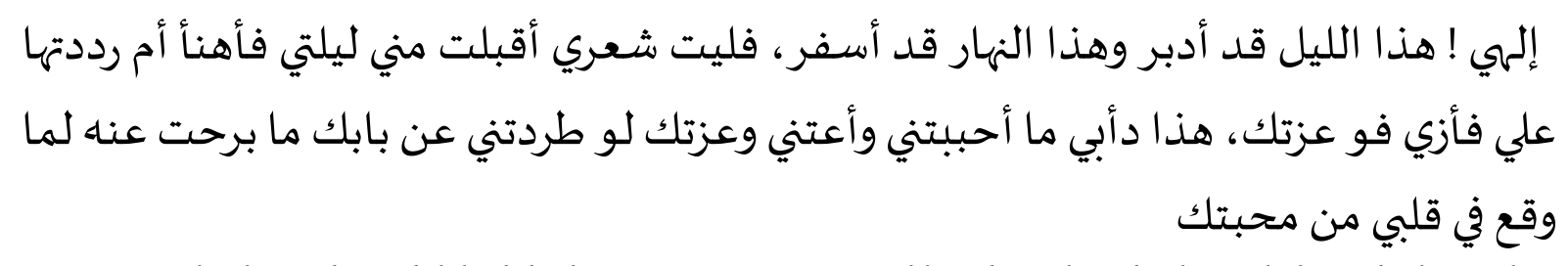

"Tuhanku, malam telah berlalu dan siang segera menampakkan diri. Aku gelisah, apakah amalanku Engkau terima hingga aku merasa bahagia, ataukah Engkau tolak hingga aku merasa sedih. Demi ke Mahakuasaan$\mathrm{Mu}$, inilah yang akan aku lakukan selalma aku Engkau beri hayat. Sekiranya Engkau usir aku dari depan pintu-Mu, aku tidak akan pergi, karena cinta pada-Mu telah memenuhi hatiku." 15

Ungkapan-ungkapan ini menggambarkan rasa cinta Rabi'ah kepada Tuhan, yaitu cinta yang memenuhi seluruh jiwanya, cinta yang tak menyisakan ruang lagi untuk selain Tuhannya, hal inilah yang menjadi alasan ia menolak lamaran dari setiap orang yang datang melamarnya, bahwa dirinya hanya milik Tuhan yang dicintainya, dan siapapun yang ingin menikah dengannya, harus meminta izin kepada Tuhan. ${ }^{16}$

\section{Pembacaan Sosio-Historis Lahirnya Konsep Cinta Rabiatul Adawiyah}

Imam al-Ghazali merumuskan lima sebab yang menimbulkan kecintaan kepada Allah:

a) Kecintaan manusia pada diri sendiri, kekekalan, kesempurnaan dan keabadian hidupnya. Orang yang mengenal dirinya dan mengenal Allah dengan pengenalan yang benar, akan mencintai Allah. Hal ini karena ia tahu bahwa hanya Allah yang dapat menuruti harapan kecintaan pada dirinya.

14 Abu Ubaidillah Syariff, Kisah Rabiah al-Adawiyah:Sufi Wanita..., 108.

15 Ummu Kalsum Yunus, Ilmu Tasawuf (Makassar: Alauddin Press, 2011), 1 l $\leq$.

${ }^{16}$ Abuddin Nata, Ilmu Kalam, Filsafat Dan Tasawuf (Jakarta: PT. Raja Grafindo Persada, 2001), 171. 
b) Kecintaan kepada yang berbuat baik kepadanya dan terhadap segala sesuatu. Orang yang mengenal Allah dengan ma'rifah yang sesungguhnya akan mencintai Allah karena ia mengerti bahwa Allah adalah sebaik-baik yang berbua baik kepadanya dan kepada seluruh makhluknya.

c) Kecintaan kepada segala keindahan, sebab Allah adalah zat yang paling Indah untuk dicintai.

d) Cinta yang timbul karena saling menyesuaikan. Apabila dilihat secara batiniah, sifat-sifat baik manusia mempunyai kesesuaian dengan sifat-sifat Allah. Hanya orang-orang yang berjalan menuju Allah yang yang dapat membuka rahasia kesesuaian tersebut dengan membiasakan melakukan ibadah-ibadah kepada Allah. ${ }^{17}$

Dari beberapa sebab yang disebutkan oleh al-Ghazali, keadaan hidup yang dialami Rabi'ah menjadi dasar dalam menempuh jalan cinta. Sejak kecil ia mendapati kehidupannya di dunia yang sangat kejam. Ketika dia sebatang kara setelah ditinggal oleh kedua orang tuanya dan terpisah dari saudaranya, ia tidak menemukan orang baik yang dapat menolongnya. Yang ia temui adalah orang-orang yang melakukan kejahatan, orang yang menjual orang lain sebagai dagangan, dan orang yang memelihara orang lain sebagai hamba. Rabi'ah sendiri adalah korban dari peristiwa-peristiwa tersebut, ia tidak menemukan seorangpun yang dapat melindungi dan menolongnya dalam kesendirian. Hanya bekal agama yang diwariskan orang tuanya yang membuatnya menyadari bahwa hanya Allah yang dapat dijadikan sebagai satusatunya pengharapan yang dapat menolong dan melindunginya dari berbagai macam penderitaan.

Dalam menunjukkan cintanya, Rabi'ah seringkali mempertanyakan tentang keridhaan Allah terhadap dirinya:

"Oh Tuhanku, aku seorang anak yatim yang teraniaya. Aku terbelenggu dalam penghambaan. Namun aku akan sabar dan rela menanggung penderitaan yang sedang menimpaku. Namun demikian aku tidak kuasa menahan penderitaan yang lebih hebat yang sedang mengganggu perasaan hatiku karena masih bertanya-tanya dan masih belum mendapat jawabannya; apakah Engkau meridhaiku?"18

Adapun faktor-faktor yang menghantarkan Rabi'ah mencapai tingkat cinta Ilahi adalah:

a) Bekal pembentukan karakter dan warisan ilmu agama yang diwarisi dari ibu dan ayahnya

Pengalaman keagamaan adalah seluruh aktivitas manusia dalam memeluk dan menjalankan agama dengan segala macam praktik-praktiknya. Dalam menjalankan perintah agama terkandung pengertian ketaatan dalam beragama. Berdasarkan pengalaman keagamaannya yang dimulai sejak masih kanak-kanak Rabi'ah mencapai puncak kematangan dan mendapat pengertian tentang cinta yang tulus kepada Allah swt.

\footnotetext{
17 Hamka, Tasawwuf Pemurnian dan Pengembangannya, (Jakarta, Pustaka Panjimas, 1993), 75.

18 Abu Ubaidillah Syariff, Kisah Rabiah al-Adawiyah:Sufi Wanita..., 95.
} 
Rabi'ah tumbuh dan besar dalam lingkungan keluarga biasa dengan kehidupan orang shaleh yang penuh zuhud. Seperti anak-anak sebayanya, Rabi'ah tumbuh dan dewasa secara wajar. Yang menonjol adalah ia kelihatan cerdik dan lebih lincah dibanding kawan-kawannya. Nampak juga dalam dirinya, pancaran sinar ketakwaan dan ketaaan yang tidak terdapat pada teman-temannya."

Berdasarkan keterangan di atas, dapat diambil pengertian bahwa kecerdikan yang dimiliki Rabi'ah di atas rata-rata. Bila dianalisa lebih jauh, perkembangan intelegensia sangat besar pada usia kanak-kanak di bawah lima tahun dan mulai menetap pada masa akhir remaja. Selain IQ pada masa anak-anak, penting juga menjaga perkembangan IQ pada saat masih dalam kandungan (pranatal). Faktor terpenting yang harus diperhatikan adalah pengaturan makanan, menjaga kesehatan, dan menjaga ketenangan batin. Agaknya, faktor terakhir ini juga mendominasi kehidupan Rabi'ah ketika dalam kandungan. Sedang pasca kelahiran, menanamkan jiwa kasih sayang merupakan salah satu faktor yang menghantarkan Rabi'ah untuk memiliki IQ yang tinggi. Keistimewaan dan kekuatan daya ingatan Rabi'ah juga telah dibuktikan sejak masa kanak-kanak, ia telah menghapal al-Qur'an 30 juz pada usia 10 tahun.

Pendidikan Rabi'ah, dalam beberapa khazanah penulisan disebutkan bahwa Rabi'ah tidak pernah sekolah secara formal seperti al-kuttab, namun Rabi'ah dididik secara langsung oleh ibu dan ayahnya. Ayah Rabi'ah menginginkan agar anaknya terpelihara dari pengaruh yang tidak baik. Oleh sebab itu, Rabi'ah sering dibawa oleh ayahnya ke sebuah mushalla yang berada di pinggiran kota Bashrah. Hal tersebut dimaksudkan agar Rabi'ah terhindar dari polusi akhlak yang melanda kota Bashrah. Di tempat inilah ayah Rabi'ah sering melakukan ibadah dan munajat, berdialog dengan sang khalik. Inilah kiranya, yang dapat dikategorikan sebagai "pendidikan khusus" yang didapatkan Rabi'ah semasa kecil dari ayah sekaligus gurunya. ${ }^{19}$

b) Keadaan sosial-politik yang kacau. Hal ini menimbulkan kemelaratan, kelaparan dan penghambaan.

Dalam sejarah disebutkan bahwa sepeninggal Umar bin Adul Aziz, kekuasaan khalifah berada di tangan Yazid ibnu Abd al-Malik (720-724 M). Khalifah Yazid terlalu condong pada kemewahan dan kurang memperhatikan rakyatnya. Masyarakat yang sebelumnya hidup dalam ketentraman dan kedamaian berubah menjadi kacau. Dengan latar belakang dan kepentingan etnik-politik, masyarakat menyatakan pertentangan terhadap pemerintahan Yazid ibnu Abd alMalik. Kerusuhan terus berlanjut hingga masa pemerintahan berikutnya, Hisyam ibnu Abd al-Malik (724-743 M), bahkan ketika itu muncul kekuatan baru, golongan mawali. Sementara itu, khalifah yang tampil berikunya bukan hanya lemah, tetapi juga bermoral rendah. ${ }^{20}$

Kota Bashrah yang menjadi pusat ilmu pengeahuan itu berubah menjadi pusat pertentangan. Di kota tersebut terdapat pengikut khawarij dan syi'ah yang

\footnotetext{
19 Abu Ubaidillah Syariff, Kisah Rabiah al-Adawiyah:Sufi Wanita..., 39.

${ }^{20}$ Abu Ubaidillah Syariff, Kisah Rabiah al-Adawiyah:Sufi Wanita..., 48.
} 
fanatik. Hal ini menjadi puncak munculnya pemberontakan-pemberontakan antara peduduk Bashrah. Pertentangan antara aliran tersebut menyebabkan pertumpahan darah.

Selanjutnya kota Bashrah mengalami bencana alam berupa kemarau panjang, kekeringan yang berkepanjangan menyebakan kelaparan penduduk kota. Kota yang mulanya makmur dan berkembang, berubah menjadi kota yang dilanda kemiskinan. Keadaan diperparah dengan meningkatnya pencurian dan perampokan. Hal ini tidak hanya membuat menderita, tetapi juga dilanda ketakutan. Orang miskin semakin miskin dan terlunta-lunta, mereka sering dihadang perampok kemudian dijual sebagai hamba.21

Keadaan Rabi'ah dan kakak-kakaknya semakin parah, sehingga mereka terpaksa meninggalkan gubuk mereka. Mereka berkelana ke berbagai daerah untuk mencari kehidupan yang layak. Dalam pengembaraan ini, menyebabkan Rabi'ah terpisah dari kakak-kakaknya. Rabi'ah kemudian jatuh ke tangan perampok dan dijual sebagai hamba sahaya dengan harga yang sangat murah, yaitu enam dirham.

c) Konsep Raja' dan Khauf yang begitu berkembang di kalangan masyarakat. ${ }^{22}$

Konsep khauf dan raja' yang berkeang pada saat itu membuat Rabi'ah meneukan kejanggalan dalam penghambaan seseorang kepada Ranya. Bagi Rabi'ah penghambaan seseorang kepada Allah karena mengharapkan balasan keamanan dari rasa takut dan harapan balasan syurga justru melatih jiwa seseorang untuk selalu mengharakan imbalan atas apa yang mereka perbuat. Sedangkan penghambaan kepada Allah bukanlah sesuatu yang diharuskan mendapat balasan apapun. Cinta yang dimiliki seorang hamba kepada Tuhannya adalah cinta yang tak membutuhkan apapun selain yang dicintainya yaitu Allah swt. Pengembangan konsep cinta ilahiah ini merupakan perpanjangan dari konsep tersebut, meski demikian cinta ilahiah adalah cinta yang tulus, menurutt Rabi'ah. Salah satu syair yang terkenal tentang hal ini adalah;

"Tuhan

Apapun karunia-Mu untukku di dunia

Hibahkan pada musuh-musuh-Mu

Dan apapun karunia-Mu untukku di akhirat

Persembahkan pada sahabat-sahabat-Mu

Bagiku cukup Kau

Tuhan

Bila sujudku pada Mu karena takut nereka

Bakar aku dengan apinya

Dan bila sujudku pada-Mu karena damba surge

Tutup untukku surge itu

Namun, bila sujudku demi Kau semata

Jangan palingkan wajah-Mu

${ }^{21}$ Abu Ubaidillah Syariff, Kisah Rabiah al-Adawiyah:Sufi Wanita..., 49.

${ }^{22}$ Abu Ubaidillah Syariff, Kisah Rabiah al-Adawiyah:Sufi Wanita..., 97. 


\section{Aku rindu menatap keindahan-MU"23}

\section{Mewarisi Cinta Ilahiah Rabi'atul Adawiyah}

Ajaran tentang mencintai Allah merupakan peran yang dilakukan oleh rasulullah saw. Namun gambaran cinta yang dijelaskan rasulullah tidak bersifat khusus, karena bagaimanapun rasulullah tampil sebagai sentral dalam setiap ajaran Islam dalam berbagai sisi.

Kisah cinta yang dimiliki Rabi'ah bukan hanya dongeng penghantar tidur, atau sebuah kisah yang berahir pada satu nyawa dan satu masa, namun sebuah kisah yang harusnya melahirkan kesadaran dalam hati setiap insan, kisah Rabi'ah adalah kisah yang harusnya menjadi warisan yang sangat berharga. Mencintai adalah level tertinggi yang diinginkan dan diimpikan bagi dan untuk sesama terlebih bagi sang maha pencipta. Menurut al-Sarraj mahabbah mempunyai tiga tingkatan:

1. Cinta biasa, yaitu keadaan selalu mengingat Tuhan dengan zikir, suka menyebut nama-nama Allah dan memperoleh kesenangan dalam berdialog dengan Tuhan senantiasa memuji Tuhan

2. Cinta orang yang siddik, yaitu orang yang mengenal Tuhan, mengenal sifat-sifat Kebesaran dan kemahakuasaan-Nya. Cinta yang dapat menghilangkan tabir seseorang dari Tuhan sehingga dapat melihat rahasia-rahasia Ilahi. Cinta yang kedua ini membuat seseorang sanggup menghilangkan kehendak dan sifat-sifatnya sendiri dan menautkan hatinya secara penuh dengan perasaan cinta pada Tuhan dan selalu rindu pada-Nya.

3. Cinta orang yang 'arif, yaitu orang yang tahu betul tenang Tuhan. Yang dilihat dan dirasa bukan lagi cinta tapi diri yang dicintai. Akhirnya sifat-sifat yang dicintai masuk ke dalam diri yang mencintai. ${ }^{24}$

Cinta ilahiah yang dimiliki Rabi'ah hampir sering dikisahkan dalam bentuk utuh. Artinya cinta yang dimilikinya seolah didapatkan dengan mudah layaknya peberian utuh dari Allah swt. Cinta ilahiah yang digagas oleh Rabi'ah juga layaknya cinta yang mustahil dan tidak dapat disentuh. Meskipun pesan cinta yang ingin disampaikan oleh Rabi'ah terlihat vertikal, namun dapat dilihat bahwa latar belakang bahkan pesan yang ingin dicapai oleh Rabi'ah adalah menyemarakkan cinta yang tulus hanya kepada Allah.

Kritik khauf dan raja' yang dimilki Hasan Bashri misalnya. Bagi Rabi'ah penghambaan seseorang kepada Allah karena mengharapkan balasan keamanan dari rasa takut dan harapan balasan syurga justru melatih jiwa seseorang untuk selalu mengharakan imbalan atas apa yang mereka perbuat. Sedangkan penghambaan kepada Allah bukanlah sesuatu yang diharuskan mendapat balasan apapun. Cinta yang dimiliki seorang hamba kepada Tuhannya adalah cinta yang tak membutuhkan apapun selain yang dicintainya yaitu Allah swt.

Hal ini terlihat ketika pada suatu hari Rabi'ah berjalan membawa obor di sebelah tangannya dan air di tangan yang lainnya. Orang-orang bertanya kepadanya "wahai perempuan anti dunia, kemana engkau akan pergi dan apa makna tindakanmmu ini?" Rabi'ah menjawab: "Aku akan menyalakan api di dalam syurga dan menyiramkan air ke neraka hingga

${ }^{23}$ K. Permadi, Pengantar Ilmu Tasawuf (Jakarta: PT. Rineka Cipta, 1997), 128.

24 Mina Wati, “Konsep Mahabbah Dan Ma'rifah dalam Tasawuf Dzunnun al-Mishri”, Skripsi UIN Sunan Kalijaga Yogyakarta, 2017. 5. 
tersingkaplah tabir yang menutup jalan orang-orang yang menuju kepada Allah, akan jelas tujuan mereka dan akan mereka saksikan Allah. Mereka tidak dihalangi oleh harapan dan tidak pula oleh rasa takut. Apakah jika tidak ada syurga dan neraka, tidak ada orang yang beribadah dan mentaati Allah?".

Cerita ini seolah-olah memberikan kita informasi tentang betapa geramnya Rabi'ah terhadap prilaku orang-orang yang menjadikan cinta kepada Allah sebagai alat penukar untuk keamanan mereka. Ini juga menunjukkan bahwa Rabi'ah memperhatikan lingkungannya, ia juga menjelaskan tentang bagaimana mencintai Allah dengan tulus tanpa mengharakan apapun. Agar mereka tak lagi terfokus hanya pada diri sendiri melainkan Allahlah pusat segalanya.

Keadaan Bashrah pada saat itu juga turut serta membuat Rabi'ah menjadikan fokus utama dalam hidupnya hanyalah Allah swt. Rabi'ah sebagai seorang yang tak memiliki apapun, tidak harta, tidak pula kedudukan dan tidak pula pengetahuan tentang pergulatan politik yang terjadi selain hanya menjadi perempuan yang ternyata turut menjadi korban atas berbagai peristiwa yang terjadi. Bagaimanapun, yang dirasakan oleh Rabi'ah hanyalah penderitaan. Rabi'ah hanya menginginkan ketenangan dalam hidupnya, ia tak bisa berbuat banyak untuk memperbaiki sesuatu yang tak ia pahami sehingga ia menyandarkan dan menyebarkan cinta dan ketulusan untuk Tuhannya. Sedikit tidak, seseorang yang berusaha kembali kepada Tuhannya akan mengurangi kecintaan kepada dunia, dan akhirnya mengurangi pertikaian dan kerusakan yang terjadi atas dasar kekuasaan dan harta benda.

Cinta Rabi'ah bukanlah cinta yang tak tersentuh, bukanlah cinta yang hanya bisa digapai satu orang melainkan cinta yang bisa diraih oleh siapa saja yang memiliki tekad, keinginan, dan kemauan yang besar. Persolan mencintai ilahi adalah persoalan individu dengan sang khaliknya. Kehidupan dan pengalaman cinta Rabi'ah justru memberikan jalan cinta yang sangat terang. Cinta seorang hamba yang hanya menjadikan Dia sebagai-satusatunya dalam hidupnya, jalan yang bisa menjadi petunjuk bagi siapapun yang ingin membuka hati dan cinta yang tulus kepada Tuhannya.

Hubungan Rabi'ah dengan dunia juga tidak sejauh itu, bagaimanapun sebagai manusia biasa, Rabi'ah harus melanjutkan hidup dengan memenuhi kebutuhan hidupnya. Perjuangannya bekerja untuk menyeberangkan orang bukanlah pekerjaan yang mudah bagi seorang perempuan, terlebih di masa itu dengan usia Rabi'ah yang masih sangat muda. Pengalaman Rabi'ah mencari pekerjaan dari rumah ke rumah hingga meninggalkan kampung halaman juga menunjukkan bahwa Rabi'ah selalu berusaha berdamai dengan dunia. Bahkan setelah Rabi'ah dimerdekakan oleh tuannya, Rabi'ah diceritakan menjadi penyanyi untuk memenuhi hidupnya, namun ini tak berarti ia menjadi pecinta dunia melainkan ia menggunakan dunia untuk berjumpa dengan Tuhannya. Hal ini sebagaimana diceritakan tentang orang yang bertanya kepada Rabi'ah, "Dari mana engkau?" "Dari dunia lain," jawabnya. "akan ke mana engkau?" "ke dunia lain," jawabnya. "Di dunia ini, apa yang engkau lakukan?" tanya mereka. "Aku memperolok-oloknya." "Bagaimana bisa demikian?" "aku memakan makanan dunia ini, tetapi menyibukkan diri dengan berbagai urusan akhirat".

Maksud dari memperolok-olok dunia adalah, Rabi'ah hanya menggunakan dunia sebagai jalan dan alat untuk menyembah Allah swt, ia memanfaatkan dunia sesuai dengan kebutuhannya, ia tidak memberikan dirinya kesempatan untuk bergantung kepada dunia. Maka dari sini dapat kita simpulkan bahwa rasa ketergantungan dan keserakahan terhadap 
dunialah yang tak bisa bersanding dengan rasa cinta kepada Allah. Nabi sulaiman adalah salah seorang Nabi dan Rasul yang memiliki kekayaan yang berlimpah, namun tak mengurangi kecintaan yang dimiliki kepada Allah swt.

\section{KESIMPULAN}

Konsep cinta Ilahiah yang telah digaungkan oleh Rabi'atul Adawiyah adalah mencintai Allah hanya karena Dia adalah Tuhan yang harus dincintai, tanpa mengharapkan balasan apapun selain hanya bersama dengan yang dicinta. Pengalaman cinta yang coba ditawarkan dalam kisah Rabi'ah bukanlah cinta yang ia dapatkan dengan mudah layaknya perasaan yang ditancapkan Allah semenjak ia lahir, walaupun pada hakikatnya alasan ini juga tidak bisa diabaikan seutuhnya mengingat cerita tentang ayahnya yang bermimppi dengan nabi. Meski demikian secara sosio historis, cinta yang dimiliki Rabi'ah adalah cinta yang ia dapatkan dalam proses panjang dari pengalaman hidupnya sejak ia kecil. Lahir dari orang tua miskin yang taat menjadikan Rabi'ah pribadi yang mandiri dan religius. Penanaman karakter yang kuat dalam beragama merupakan bekal yang ia gunakan dalam proses pencarian cinta yang hakiki.

Cinta yang dimiliki Rabi'ah adalah cinta yang penuh perjuangan, hubungannya dengan dunia memperlihatkan bagaimana Rabi'ah memposisikan dunia sebagai jembatan menunju cinta-Nya. Rabi'ah tetaplah bersanding dengan dunia untuk mendapatkan manfaatnya, namun ia tak mengizinkan hatinya untuk bergantung pada selain yang maha kuasa. Sisi lain yang bisa dilihat dari cinta ilahiah Rabiatul Adawiyah adalah bagaimana ia berusaha untuk mendakwahkan dan menjelaskan tentang konsep cintanya kepada masyarakat melalui syairsyair dan tindakan yang ia lakukan. Cinta yang tulus hanya kepada Allah dan karena Allah, bukan untuk mendapatkan balasan apapun termasuk nikmatnya syurga dan perlindungan dari panasnya api neraka, sebagaimana konsep raja' dan khauf yang berkembang pada saat itu.

Menurut penulis, konsep cinta ilahiah adalah salah satu bentuk perjuangan dan kritik terhadap keadaan masyarakat dan politik yang terjadi pada saat itu. Rabi'ah tampil menjadi yang berbeda di tengah kebergantungan orang terhadap dunia, harta, dan tahta serta kebringasan masyarakat untuk meraihnya. Rabi'ah menunjukkan cinta ilahiahnya di tengah masyarakat dengan kemerosotan akhlak dan moral. Pergulaan politik yang terjadi serta dampaknya terhadap masyarakat menjadikan Rabi'ah menempuh jalan cinta untuk menenangkan diri dan menebarkan cinta pula untuk memahami kembali tentang esensi penciptaannya sebagai manusia, yaitu untuk beribadah kepada Allah semata. Mengingat kembali pengertian cinta dan kisah cinta ilahiah Rabi'ah ini, menyadarkan kembali bahwa cinta adalah rasa yang ada di dalam hati, namun ia juga membutuhkan usaha, perjuangan dan riyadhah untuk mendapatkanya. Namun jika ditanyakan lebih dalam, bahwa di hati orang yang beriman akan terasa bahwa ada cinta yang tercipta, cinta seorang hamba kepada Tuhannya. 


\section{DAFTAR PUSTAKA}

Abu Ubaidillah Syariff. T.th. Kisah Rabiah al-Adawiyah:Sufi Wanita dan Aroma Cinta Ilahi. Kuala Lumpur: Jasmin Enterpaise

Abuddin Nata. 2001. Ilmu Kalam, Filsafat Dan Tasawuf. Cet. V. Jakarta: PT. Raja Grafindo Persada, Hamka. 1993. Tasawwuf Pemurnian dan Pengembangannya Jakarta: Pustaka Panjimas

Hasan Bakti Nasution dan Sahrini Harap. 2003. Ensiklopedi Aqidah Islam. Jakarta: kencana.

K. Permadi. 1997. Pengantar Ilmu Tasawuf. Jakarta: PT. Rineka Cipta.

M. Quraish Shihab. 2018. Perempuan. Tanggerang: Lentera Hati.

Mina Wati. 2017 "Konsep Mahabbah Dan Ma'rifah dalam Tasawuf Dzunnun al-Mishri”, Skripsi sarjana tak diterbitkan, UIN Sunan Kalijaga Yogyakarta.

Muhammad Al-Faqi. 1979. Al-Tasawwuf Hayat wa Suluk. Kairo.

Simuh. 1996. Tasawuf dan Perkembangan Dalam Islam. Jakarta: RajaGrafindo Persada.

Ummu Kalsum Yunus. 201l. Ilmu Tasawuf. Makassar: Alauddin Press 